Article

\title{
Students' Perspective on Quality Assurance in Higher Education in the Context of Sustainability: A PLS-SEM Approach
}

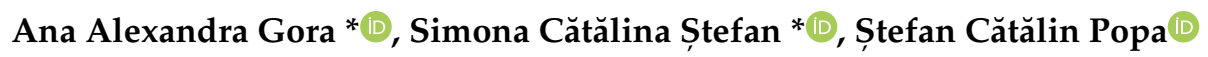

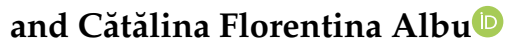 \\ Management Department, The Bucharest University of Economic Studies, 010374 Bucharest, Romania \\ * Correspondence: anaalexandra.gora@gmail.com (A.A.G.); simona.stefan@man.ase.ro (S.C.S.)
}

Received: 16 May 2019; Accepted: 28 August 2019; Published: 3 September 2019

\begin{abstract}
The purpose of this paper was to provide empirical evidence of the impact of quality assurance in higher education on two relevant higher education outcomes; students' knowledge, skills, and competencies; and their employability. Survey data were collected from two major Romanian public universities and analyzed using a partial least-squares structural equations modeling (PLS-SEM) technique. The main results suggested that students' competencies were positively and directly influenced by the quality of the educational process, as well as the practical and research activities. The students' chances of employment in the labor market were positively and directly influenced only by the quality of the educational process and by the research activities. Indirect influences were also revealed. The findings of the study may be shown to have theoretical implications by proposing a model that links the features of quality management in higher education institutions with students' competencies and chances of employment in the labor market. From a practical perspective, the results may be of interest to higher education policy makers, to evaluation and accreditation institutions, to universities, and also to students.
\end{abstract}

Keywords: competencies; employability; higher education system; quality management; students; sustainability

\section{Introduction}

In recent decades, as Polyakova [1] states, globalization and the process of simultaneous national, international, and multicultural integration have affected all areas of life, including political, social, economic, and educational aspects. In a world in which globalization is a central element, transversal competencies are fundamental in all areas of professional activity [2], since they nuance and strengthen professional competencies [3], and it is vital for every citizen to use his transversal competencies in an international context [4]. Thus, these competencies have become key elements in any field, because they highlight the performance of a person. In this context, one of the major challenges for companies in measuring their success will be their ability to recognize and develop unidentified competencies on a continuous basis [5].

The shift from student to employee status has become an important aspect of the labor market for students and for universities [6]. The issue of ensuring a match between the education system and, more precisely, between vocational training and the dynamics of the labor market has become a more and more common obstacle. In Romania, there are still concerns in this respect, which is evidenced by the existence of projects, such as the Sectorial Operational Program Human Resources Development 2007-2013 [7], which has a priority axis (Priority Axis 2) on the "Correlation of lifelong learning with 
the labor market," aiming to improve the process of insertion into the labor market of students and the development of some competencies that correlate with the requirements that exist in the labor market.

At the moment, as Sá and Serpa [8] also maintain that the labor market is blocked and is rapidly changing due to the occurrence of new professional and scientific fields, and implicitly, new jobs make the mission of higher education more and more challenging and less indisputable. The higher education system is in a moment of transition, and universities need to discover new ways of attracting students and, moreover, preparing them for the current job market and ensuring the sustainable development of society [9].

Currently, in the context of increasing economic, social, and environmental challenges, the idea of sustainability has evolved [10]. An increased education, in terms of sustainable development and sustainable practices, is required [11], and governments, companies, and educational institutions have concerns about encouraging, developing, and implementing sustainable behaviors [10,12]. According to Fuertes-Camacho et al. [13], sustainability competencies are the basic skills that lead people to adopt a balanced lifestyle in terms of economic growth, respect for the environment, and social justice. Moreover, under the conditions of globalization and the continuous development of society, higher education institutions should function as places for the research and learning of sustainable development [14] by replacing the traditional curriculum with a modern one, oriented towards the development of competencies that could ensure the sustainability of universities. Regarding this necessity, nowadays, there is considerable progress in the inclusion of sustainable development in the curricula of higher education institutions [15]. In addition, this new curriculum should be accompanied by new teaching and learning methods that allow students to develop as many competencies and skills as possible. In this way, the curricula will impact the skills and competencies of students relating to their employability and will improve their chances of professional development in a turbulent business environment [16].

As Lambrechts et al. [17] mentioned, the call for education to contribute to a sustainable society has become a new challenge and is characteristic of the current century of higher education. The current role of the higher education system to ensure full education involves conveying not only a series of technical skills, but also other competencies, such as [18]: communication skills, teamwork skills, project and time management skills, and emotional coordination capacities. In addition, universities need to adapt their educational offering to the needs of the labor market and equip students with transferable skills [8], which will enable them to apply the acquired knowledge in different professional fields.

Students should also develop sustainable competencies, which represent a combination of knowledge, skills and attitudes that help to solve sustainability issues in the surrounding world [19-21]. Currently, all stakeholders in higher education institutions have an important role in the development of sustainable competencies among students [22]. According to Rieckmann [19], universities play an important role in shaping the future of societies around the world in terms of sustainable development, since they generate new knowledge among the students and contribute to the development of appropriate competencies and sustainability awareness. Thus, universities play a crucial role in the field of sustainable development and must prioritize the integration of sustainable development into education programs [23]. In order to develop such competencies for sustainability, higher education institutions must create a teaching and learning framework [21] and should introduce sustainable development into its curricula, helping students, as future employees in the labor market, to face the problems of sustainable development in the workplace [24].

Novo-Corti et al. [25] argue that education is a key factor in ensuring sustainable development, since, through education, people learn to become more responsible for the environment. In this context, higher education institutions need to become sustainable in order to contribute to the creation and development of a sustainable society. Elliott and Wright [26] believe that universities are well placed to educate and influence future leaders on the goals and importance of sustainability, and Murray [10] believes that, in recent years, universities have been recognized as the ideal leaders in the development 
of policies and innovative solutions needed for the transition to sustainable societies. A significant role in the direction of this evolution is given to students.

Given the important role of competencies in the current context of globalization and sustainability, universities have the responsibility not only to enable students to develop the necessary skills in the labor market, but also to contribute to the sustainable development of society. In this sense, studying the link between universities and the development of sustainable competencies and the way in which a number of factors specific to higher education (the quality of the educational process, the infrastructure and technical equipment, and practical and research activities) influence students' competencies (such as knowledge and competencies in the field of specialization, communication competencies, teamwork skills, organizational skills and competencies, analytical and problem-solving skills and entrepreneurial skills) and their chances of employment in the labor market may be required. Starting from the above, two research questions can be formulated, namely:

RQ1.How does the quality of the educational process, the infrastructure and technical equipment, the practical activities, and the students' research activities influence the knowledge/competencies/skills acquired by the students?

RQ2. How does the quality of the educational process, the infrastructure and technical equipment, the practical activities, and the students' research activities influence their chances of employment in the labor market?

In order to answer these questions, this study aimed to analyze the extent to which each of these four factors-quality of the educational process, infrastructure and technical equipment, practical activities, and students' research activities-influence the students' competencies and chances of employment in the labor market. Attaching importance to these factors has the potential to provide universities with the quality management elements they need to improve their curricula in the current context of sustainability, if they want to develop among their students a range of specific skills to increase their chances of employment in the labor market.

The paper begins with a presentation of the contextual framework and with an analysis of the specialized literature in the field. Then, the research hypotheses are developed. Next, the methodology and the results of the research are presented, and the discussion section emphasizes the connection between the quality of the educational process, the infrastructure and technical equipment, the practical activities, and the students' research activities and the influence that these factors have on the students' skills and chances of employment in the labor market. Finally, the conclusions of this research are presented, highlighting the main implications and limits of the research.

\section{Theoretical Background and Hypotheses Development}

As a key factor in any field, a person's competence highlights his/her performance. Hersey et al. [27] claim that a person has to do more than learn about one thing; he must be able to do that thing. Hey [28] defines competence as a person's ability to clearly meet performance requirements for a defined role and considers that this includes the skills and knowledge needed to carry out specific tasks. Rieckmann [19] presents competence as an interplay of knowledge, capacities, skills, motives, and affective dispositions. Concerning the same subject, Herppich et al. [29] describe it as a set of cognitive devices specific to a particular context, which are acquired and necessary to deal with situations or tasks in some specific domains. Starting from this definition, it can be noticed competencies are not genetic abilities, but are acquired over the course of a person's life, and in this regard, the education system has a decisive role.

The Project Management Institute, as quoted in Dada and Jagboro [30], define competence as a group of knowledge, skills, attitudes, and other personal characteristics that affect much of the workplace and correlate with site performance, and it can be measured by well-established standards. Employability is defined by Knight and Yorke [31] (p. 5) as: "a set of achievements, understandings and personal attributes that make individuals more likely to gain employment and be successful 
in their chosen occupations". In addition, Knight and Yorke [32] identified four ways of enhancing student employability: work experience, entrepreneurship modules, careers advice and portfolios, profiles and records of achievement. Thus, one may see that there is a close link between competencies and the workplace, as well as, implicitly, between competencies and chances of employment in the labor market.

Regarding the specifics of competencies relating to employment in the labor market, whether they are communication-related, team work-related, organizational, or entrepreneurial, it can be stated that it is necessary for them to be acquired by any individual, because they outline his/her personality and represent his/her competitive advantage through which he/she is distinguished from others. By means of competencies acquired over time and applied in the workplace, people could add value to the labor market, and it is therefore important to identify those jobs for which competence is a priority and to define what skills are needed for each job.

Skills development combines formal education with tacit knowledge and competencies gained through work experience [33], and competence-based higher education helps students to obtain important knowledge, skills, values, and attitudes, which they will require in their future personal and professional lives [17]. Thus, it may be noted that education institutions have a key role in developing the skills needed for a future job, because they offer formal education but can also help students to develop skills through the practical activities that they provide to students.

At the level of higher education institutions, two key issues need to be dealt with, when referring to students' competencies/knowledge/skills and their correlation with the labor market [9]: (1) how universities can communicate better with students the skills and knowledge they need to acquire, and (2) how they can make them understand and use these skills in their future jobs.

In this context, starting from the definitions of competence and the role of universities in developing students' competencies, it is important to identify the most important competencies that students should acquire to contribute to a sustainable future and to identify which competencies could be seen as key sustainability competences.

Rieckmann [19] (p. 133) identified that the following key competencies are critical for sustainable development and for a sustainable future: competency for systemic thinking and handling of complexity, anticipatory thinking, critical thinking, acting fairly and ecologically, cooperation in (heterogeneous) groups, participation, empathy and change of perspective, for interdisciplinary work, communication and use of media, planning and realizing innovative projects, evaluation and competency for ambiguity and frustration tolerance.

Wiek et al. [20] conducted a broad literature review and identified the relevant literature on key competencies in the field of sustainability. The set of key competencies for sustainable development, proposed by Wiek et al. [20] includes the following competencies: systems-thinking competence, normative competence, anticipatory competence; strategic competence; and interpersonal competence.

Ploum et al. [34] analyzed the frameworks of key competencies in the field of sustainable development, compiled by several researchers, and identified six key competencies, which constitute a competence framework that can be used to support sustainable entrepreneurship and, implicitly, a sustainable future: strategic management and action competence; diversity competence; systems thinking competence; normative competence; foresighted thinking competence; and interpersonal competence.

Bratianu and Vatamanescu [16] believe that, in order to develop students' thinking skills, it is necessary to develop a different approach, promoted by teachers and a greater involvement of students in the learning process. In their study, five generic thinking skills are analyzed [16]: (1) researching, collecting, and organizing data, information, and knowledge; (2) problem-solving; (3) creative thinking; (4) learning to learn; and (5) strategic thinking.

A number of students' perception studies have been conducted on the topic studied in this research [35-39]. Thus, Nicolescu and Nicolescu [35] used PLS-SEM to construct an employability confidence model for business students using the skills relating to employability. The findings show 
that four categories of skills and, more exactly, personal qualities, transferable social skills, professional skills and job seeking skills, have positive and significant impact on students' employability confidence, while the other categories of skills and, more precisely, corporate-related skills and individual transferable skills, do not significantly influence employability confidence. Lambrechts and Van Petegem [36] analyzed the interrelations existing between the sustainable development competencies and research competencies, and their findings illustrate that research competencies are often found to contribute to the acquisition of students' sustainable development competencies.

Kagawa [37] explores the perceptions, the understandings and the attitudes of students from Plymouth towards sustainable development and related concepts and issues. The findings of this study show that students think that sustainability is "a good thing", but their positive response does not particularly correlate with their familiarity with the concepts of sustainable development or sustainability. In this respect, Zsóka, Szerényi, Széchy, and Kocsis [38] emphasize the importance of understanding the attitudes and behavior of students regarding the environment and the importance of finding effective ways to influence this behavior through education. As well, Lambrechts et al. [39] conducted a study on 458 students in business management/marketing from a Belgian Higher Education Institution to investigate the students' perspectives on sustainability and the possible consequences for competence-based higher education. This study is a segmentation study that frames the variety of student dispositions relating to sustainability attitudes. Four different segments were identified, each with particular characteristics and opinions toward sustainability issues: "moderate problem solver", "pessimistic nonbelievers", "optimistic realists" and "convinced individualists". All these segments of students show that it is complicated to capture opinions on sustainability issues in general terms and that it is necessary to prepare students for dealing with the complexity of sustainability issues, focusing on developing critical and interpretational competencies among students.

Analyzing all these studies, it can be observed that it is becoming a priority for universities to modify and develop their curricula in order to integrate sustainability issues and to create a favorable framework for the development of specific competencies in order to contribute to the development of a sustainable future.

Taking the current stage of knowledge and the questions underlying this research as a starting point, it may be considered important to study the existing link between a series of quality management elements in higher education institutions (the quality of the educational process, the infrastructure and technical equipment, the practical activities and the students' research activities) and the students' competencies and their chance of employability in the labor market, from the point of view of students' perception of these elements. In this context, a series of hypotheses, regarding the relationship between the key factors underlying management and quality assurance in the higher education system and the acquired knowledge/competencies/skills of students, as well as their chances of employment, will be formulated. As far as competencies are concerned, this paper considered the following as key competencies that can facilitate a sustainable future: Knowledge and competencies in the field of specialization; Communication skills/competencies; Teamwork competencies; Organizational skills and competencies; Analytical and problem-solving skills; and Entrepreneurial skills.

An important role in the development of didactic activities is accorded to the infrastructure and technical equipment of the universities and, more precisely, the material basis of the university (endowment of the classrooms, of laboratories, etc.) and the library services offered to the students. This is necessary for students to deepen their knowledge in the field of specialization and not only to allow them to form a series of competencies and learn a set of skills necessary for further integration into the labor market. Starting from this factor, the following research hypotheses can be formulated:

Hypothesis 1 (H1). Universities' infrastructure and technical equipment positively influence students' knowledge/competencies/skills. 
Hypothesis 2 (H2). Universities' infrastructure and technical equipment positively influence students' employability.

Besides infrastructure and technical equipment, the educational process has an important role in determining the quality of higher education. The quality of the educational process has become a key decision factor, which provides higher education policy makers with evidence to support their decisions concerning the design of curricula, study, and programs. In the present paper, the quality of the educational process encompasses the quality of the content of the educational process, the quality of the teaching staff, and the quality of the teaching activities.

As higher education systems are pressed to increase their effectiveness in different ways, it becomes more important and even necessary to improve the quality of teaching and learning [32]. Over time, concerns have been stepped up in the field of quality management; at present, all actors involved in the educational process (students, teachers, etc.) are trying to create a culture of quality in universities to ensure international recognition of higher educational institutions. Teachers are important stakeholders in quality assurance, because, through the quality of their teaching activities, they contribute to determining the competencies and performance of other stakeholders, namely, students. In the current context of the importance of developing competencies among students, teachers have two important tasks [40]: (1) they need to set the objectives of their activities (learning objectives, the competencies that they want to promote, etc.) and (2) decide how they want to achieve these goals. Transversal competencies are recognized as important skills of teachers not only in the educational process (teaching and learning), but also in the process of teaching and transferring these competencies to students [41]. Furthermore, teachers, as stakeholders in the educational process, need to continually impart to students the competencies needed to integrate them into the labor market and for their future career. Teachers have an important role in the educational process, because the acquisition and assessment of competencies for the sustainable development of society require different ways of teaching and learning, including experiential learning, reflective learning, practice-based learning, creativity, collaboration, problem-solving, the transdisciplinary approach, and regulation [36].

Moreover, at the European level, through the Standards and Guidelines for Quality Assurance in the European Higher Education Area (ESQ) [42], as well as in Romania, through The Romanian Agency for Quality Assurance in Higher Education (ARACIS) methodology [43] and through the periodic evaluation visit of universities [44], there are a number of mandatory normative requirements related to the content of the educational process and the didactic activities, such as the structuring of study disciplines in a logical order and the compatibility between what is studied in the courses and what is studied in seminars, in order to determine the extent to which they participate in creating the necessary competencies for employment in the labor market.

Starting from the idea that there is a link between the quality of the educational process and the skills acquired by the students, studies [6] show that there is also a connection between the curriculum, the international competencies and the chances in employment in the labor market.

At the level of the higher education system, the organization of the educational process needs to be continuously developed [45] to match the competencies they form in students and those that labor market organizations require. Thus, universities are being challenged to continually assess the labor market and the competencies required by employers [45] to redefine the content of their disciplines in order to adapt their educational offerings to the needs of the labor market [8] and to develop their own skills and competencies, required in various professional fields, in order to impart these to students. In this context, universities need to create particular learning settings, in which students can develop and improve their competencies to understand the complexity and long-term effect of them for present-day actions and, thus, contribute to a sustainable future [19].

In view of the above presented topics, the following research hypotheses, referring to the link between the quality of the educational process, the knowledge/competencies/skills acquired by students, and the chances of employment in the labor market can be proposed: 
Hypothesis 3 (H3). The quality of the educational process positively influences students' knowledge/ competencies/skills.

Hypothesis 4 (H4). The quality of the educational process positively influences students' employability.

Karna and Gotovac [46] attribute the knowledge, skills, and aptitudes needed to perform tasks at work to competencies. Therefore, it can be stated that the chances of employment in the labor market depend, to a significant extent, on the competencies acquired by the person wishing to integrate him/herself into the labor market. The permanent emergence of new types of jobs imposes a new demand for knowledge [16] and specialized competencies for integration into the labor market. Students' competencies can be improved by correlating the theoretical knowledge they acquire in universities and the competencies gained through practical activities, which help them to become acquainted with, develop themselves, and prepare for a job [47].

As far as practical activities are concerned, they play an important role in the student education process [47]. The study conducted by Butum [6], regarding students' perceptions of university performance in both Europe and Romania, illustrates that they most appreciate the professional competences they acquire over their years of study, practical activities, and the possibility of having access to international training programs. As already mentioned, teachers have a significant role in the development of students' competencies. As stated by Bratianu and Vatamanescu [16], teachers should integrate in their disciplines a series of lectures and practical activities, designed to stimulate the development of skills and competencies among students, because in recent years, the labor market has increased the demand for international and specialized competencies and skills [6]. Starting from the important role of practical activities in the field of the educational process, the following hypotheses of research can be set out:

Hypothesis 5 (H5). Practical activities positively influence students' knowledge/competencies/skills.

Hypothesis 6 (H6). Practical activities positively influence students' employability.

The identification and knowledge of employers' demands regarding the skills required at the workplace is extremely important in the process of the accumulation of human capital [48]. As Pinto [49] argues, one of the greatest concerns currently faced by higher education institutions is the development of transversal skills in students, in addition to technical and scientific ones, to help them increase their chances of integrating into the national and international labor markets and mobility and ability to live in a diverse world.

In the context of living in a society, where there is a wealth of information to which people have almost instant access, the development of research competencies has become essential [50], because research requires a critical and analytical thinking process. Lambrechts and Van Petegem [36] indicate that research competencies can be described in different ways, depending on the specific purpose or discipline for which they are used. They believe that universities integrate research competencies for two reasons [36]: (1) students acquire "instrumental" research skills ("doing research"); and (2) students acquire a critical and reflective "research attitude".

Thus, research activities play an important role in the learning and teaching process, as supported by Simons and Elen [51], who state that teaching and research can be seen together as a learning process of students (education through research) or as an instrument developed based on competencies (research-based teaching). Furthermore, Brew [52] conceptualizes the functions of research in the teaching and learning process in two ways [52]: research-based learning (offers students the opportunity to conduct research activities and develop their research competencies in the courses) and research-enhanced teaching (emphasis is placed on introducing a research specialist to teach courses). Starting from the above, the following two hypotheses regarding research can be formulated: 
Hypothesis 7 (H7). Student research activities positively influence students' knowledge/competencies/skills.

Hypothesis 8 (H8). Student research activities positively influence students' employability.

\section{Methodology}

\subsection{Measures}

In this study, for the purpose of data collection, a structured questionnaire was used. By studying the theoretical approaches to the concepts of competence, employability, quality management, etc., as well as previous studies investigating their relationships, the concepts embedded within research hypotheses were operationalized by eight constructs, each of them measured by several variables, measured on a five-point scale. Moreover, the ARACIS methodology [43] and the Standards and Guidelines for Quality Assurance in the European Higher Education Area (ESG) [42] were also considered to identify the most important dimensions of quality assurance in higher education. Therefore, the eight measurement constructs were as follows:

- Infrastructure and technical equipment. Its importance relies on the facilities that assist the professors and students in daily educational activities in achieving an optimal environment for the academic process. As specific variables, 7 items were included, such as the "Equipment of classrooms/seminars (furniture, video projectors, etc.)", "The correlation between the number of seats in the classrooms and the number of students in a series" or "The existence of appropriate software for study subjects".

- Content of the educational process. Five items were included in this category, for example: "The relevance of the study disciplines", "Structuring the disciplines of study in a logical sequence", and "The compatibility between what you study in the course and what you study in the seminar". All of these elements generally indicate the way in which the subjects and the profile of the universities should be structured.

- Teaching staff. The importance of these variables is underlined by the fundamental role of the teacher in the educational process and in training students with the most important competencies needed for employment in the labor market. Seven items were included, such as "The teacher's use of student-centered teaching methods", "The student-teacher partnership relationship", and "The resources used by the teacher in the teaching process (PPT presentations, statistics, etc.)".

- Teaching activities included 7 items, such as "The relevance of the information that is transmitted", "Actuality of the information transmitted in the course/seminars", and "The practical applicability of the information provided". This category is important, because it highlights the relevance and usefulness of didactic activities in the development and training of students.

- Research activities. The aim of this category was to determine the students' perception regarding a number of reasons for choosing to engage in research activities. Nine items were included in this category, for example: "Familiarizing with the writing of a scientific research", "Developing competitive spirit", "Personal and professional development", and the "Possibility to earn scholarships".

- Practical activities. Seven items, which highlight a number of specific aspects related to the practical activities to which the students of the two universities must participate during the years of study, were included. Additionally, the importance of this category relies on the way in which the practical activities assist students to develop some specific competence. Some of the specific aspects used in the research were "Providing access to the place of practice by the university", "The period of the specialization practice", "The concordance between the practice and the field in which you are a student", and "The way in which the specialized practice contributes to professional development". 
- Knowledge, skills, and competencies. This content was included as a result of the educational process. Six items, referring to general or transversal competencies, were included in this category, such as "Knowledge and competencies in the field of specialization", "Communication skills/competencies", "Organizational skills and competencies", and "Entrepreneurial skills".

- Employability. As specific variables, two items referring to students' chances of engaging after they have completed their studies in the field in which they have prepared or in a related field were included.

The eight measurement constructs, described above, as well as their corresponding references are presented in Table 1, while the full set of questionnaire items may be consulted in Table A1.

Table 1. Conceptual constructs and variables.

\begin{tabular}{|c|c|c|c|}
\hline Construct & Items & Variables & References \\
\hline $\begin{array}{l}\text { Infrastructure and technical equipment } \\
\text { (TEq) }\end{array}$ & 7 & TEq1-TEq7 & {$[21,43,44]$} \\
\hline $\begin{array}{l}\text { Content of the educational process } \\
\text { (Cont) }\end{array}$ & 5 & Cont1-Cont5 & {$[14,19,21,36,43,44]$} \\
\hline $\begin{array}{c}\text { Teaching staff } \\
(\mathrm{TSt})\end{array}$ & 8 & TSt1-TSt8 & {$[19,36,41,43,44]$} \\
\hline $\begin{array}{l}\text { Teaching activities } \\
\text { (TAc) }\end{array}$ & 7 & TAc1-TAc7 & {$[19,36,43-45]$} \\
\hline $\begin{array}{l}\text { Research activities } \\
\text { (Res) }\end{array}$ & 9 & Res1-Res9 & {$[14,36,43,44,50,52]$} \\
\hline $\begin{array}{c}\text { Practical activities } \\
\text { (Prct) }\end{array}$ & 7 & Prct1-Prct7 & {$[16,33,43,44,47]$} \\
\hline $\begin{array}{l}\text { Knowledge, skills, and competencies } \\
\text { (Comp) }\end{array}$ & 6 & Comp1-Comp6 & {$[7,8,19-21,34,36,39,43,44]$} \\
\hline $\begin{array}{c}\text { Employability } \\
(\text { Emp })\end{array}$ & 2 & Emp1-Emp2 & {$[7,8,35,43,44]$} \\
\hline
\end{tabular}

Source: Authors, based on the mentioned references.

The questionnaire contained closed questions, and a 5 point numerical scale was used, where 1 meant that the students did not agree with a particular statement, and 5 meant that they were totally in agreement. The questionnaire was accompanied by a series of details, where the respondents were informed about the purpose of the research, the fact that the investigation was part of a research work, and that the seriousness of the answers they provided determines the quality of the study. It was also made clear that the answers to this questionnaire were confidential and used only for scientific purposes, that the participation of the students in the present research was voluntary, and that by completing the questionnaire they had expressed their consent to confidentiality. They were also informed, from the beginning, of the time needed to complete the questionnaire.

\subsection{Participants}

This study was based on a survey-based questionnaire, which was completed by 496 respondents from two large public universities in Romania. One of them prepares students only in the economic field, while the other one has faculties in various fields, besides economics, such as education sciences, communication sciences, physical education, electrical engineering, food engineering, forestry, etc. Another reason behind the choice of these two universities was that they are located in different geographical areas.

The questionnaire was addressed to undergraduate and master students from the two universities. Students from the same faculty and specialization, who are in the same year of studies, following a certain number of topics that are included in the curricula, established at the level of the universities, were included in this research. Therefore, a criterion regarding the minimum number of subjects and academic courses cannot be considered as exclusion criteria. The research did not include students from 
distance and part-time learning and doctoral and post-doctoral students, as they, unlike undergraduate and master students, spend less time in the university, and it was considered that, without taking part in the educational process and without participating in courses and seminars frequently, students cannot express a clear and concrete opinion on the quality of the educational process.

\subsection{Procedure}

The research was conducted between February and March 2018, and the questionnaire was distributed via the online environment, since: (1) the target group included students from different geographic areas; (2) the questionnaire could be completed simultaneously by several respondents; and (3) this allowed us easier access to the collected data. Moreover, in this way, data from the respondents were automatically entered into a database, which allowed us to process them using the software. Other advantages of the online questionnaire that informed our choice to use this research method included [53]: flexibility (can be conducted and distributed in several forms and in several ways: e-mail with inquiry or e-mail with a link to a survey address), speed of data acquisition, and convenience of respondents (respondents can respond when they have time), etc.

In total, after a five-week period, 507 questionnaires were received. Cases with suspicious response patterns and missing values for more than one variable were deleted, while the remaining 496 usable ones were further analyzed. The rest of the missing data were replaced by means of an expectation maximization (EM) algorithm.

Sample representativeness was addressed, both in term of size and structure. In terms of size, considering a $95 \%$ confidence level, the sample may be considered representative, assuming a $\pm 4.3 \%$ margin of error. In terms of structure, a Chi-square Goodness-of-Fit Test was conducted to compare the distribution of the respondents in the two universities, within the sample, with the distribution of their total number of students. The test results revealed no significant differences $\left(\chi^{2}=3.372\right.$, ns), which supports the representativeness of the sample, in terms of structure. The Hair et al. [54] sample size criteria for conducting the PLS-SEM analysis were also met in this study.

\subsection{Data Analysis}

For data analysis, within this study, Partial Least Square-Structural Equation Modelling (PLS-SEM) was employed. The PLS-SEM is a second-generation multivariate data analysis technique, through which the structural model is examined with the primary purpose of explaining the variance in the dependent variables, thus being used mainly in exploratory research to develop new theories [55]. Within this study, the SmartPLS 3.2.7 application [56] of PLS-SEM was used to assess the measurement model in terms of reliability and validity and evaluate the hypothesized relationships among the latent constructs within the structural model.

\section{Results}

\subsection{Descriptive Statistics}

Regarding the structure of the sample, $66.53 \%$ of the respondents were enrolled in the first university, while $33.47 \%$ of them were enrolled in the second one. Regarding the study cycle in which the respondents are registered, $72.38 \%$ of the students were undergraduates and $27.62 \%$ of them were enrolled in a master's program. In terms of the form of study funding, $75.81 \%$ of the students who participated in this research were supported by the universities' budget and the remaining $24.19 \%$ were self-funded. In terms of the study year of the students surveyed, most of the students in the bachelor cycle were enrolled in the third year of study $(35.38 \%)$, followed by students in the second year $(33.15 \%)$, the first year $(30.36 \%)$, and the fourth year $(1.11 \%)$. Regarding master's students, $51.09 \%$ of them were enrolled in the first year and $48.91 \%$ were enrolled in the second year.

In terms of the variables measuring students' perceptions of different aspects of quality in higher education and academic outcomes, Table 2 provides some interesting information. Independent 
sample $t$-tests revealed significant differences among the students from the two universities only in terms of the infrastructure and technical equipment, $t_{(494)}=-6.167, p=0.05$. The analysis of the other factors (content of the educational process, teaching staff, teaching activities, research activities, practical activities, knowledge, skills and competencies, and employability) shows that there are differences of perception among the students of the two universities, but these are not statistically significant. Moreover, no significant differences were found between the undergraduate and master's student groups.

Table 2. Descriptive statistics of constructs.

\begin{tabular}{|c|c|c|c|c|c|}
\hline No. & Constructs & Mean & SD & $t$-Test ${ }^{a}$ & $t$-Test $^{b}$ \\
\hline \multicolumn{6}{|c|}{ Quality criteria } \\
\hline 1 & Infrastructure and technical equipment & 3.168 & 0.972 & $-6.167^{* * *}$ & 0.274 \\
\hline 2 & Content of the educational process & 3.397 & 0.973 & 1.908 & -0.458 \\
\hline 3 & Teaching staff & 3.350 & 0.974 & -0.453 & 0.060 \\
\hline 4 & Teaching activities & 3.447 & 0.908 & 0.735 & 0.939 \\
\hline 5 & Research activities & 3.603 & 0.987 & 1.843 & 0.521 \\
\hline 6 & Practical activities & 3.189 & 1.116 & 0.376 & 0.507 \\
\hline \multicolumn{6}{|c|}{ Academic outcomes } \\
\hline 7 & Knowledge, skills, and competencies & 3.417 & 1.021 & -0.078 & -0.352 \\
\hline 8 & Employability & 3.328 & 1.015 & 0.974 & 0.186 \\
\hline
\end{tabular}

\subsection{Measurement and Structural Model Assessment}

As recommended for newly developed scales, the psychometric properties of the scales measuring the considered dimensions of the quality in higher education and academic outcomes were first examined through the Exploratory Factor Analysis (EFA) procedure, prior to being included in the PLS-SEM model.

The Confirmatory Factor Analysis (CFA) procedure was run using SmartPLS software, version 3.2.7 [56]. The SEM model included three first-order constructs (Infrastructure and technical equipment, Research activities, and Practical activities) and the Educational process (a second-order construct) for the quality criteria and the Knowledge, skills, and competencies and Employability as higher education outcomes. The Educational process was considered a second-order construct, since all of the variables measuring the Content of the educational process, Teaching staff, and Teaching activities were loaded together under the same factor in EFA.

To assess the measurement model, the convergent and discriminant validity and composite reliability were considered. As can be seen in Table 3, for this measurement model, all of the quality criteria were met, since all factor loadings, Cronbach's alpha, composite reliability (CR), and average variance extracted (AVE) values were above the recommended threshold $(0.7,0.7,0.7$, and 0.5 , respectively) [55,58-61].

The discriminant validity was assessed by means of Fornell and Larcker's [60] criterion and by examining the outer loading matrix. For the analyzed constructs, all of the square roots of AVE had higher values than the inter-construct correlations, while all indicators loaded higher on their construct than all of the others, thus guaranteeing the external consistency of the model.

Once the basic quality criteria for the measurement model were met, the analysis stepped forward, and the structural model was examined in terms of the collinearity diagnostic, coefficients of determination $\left(R^{2}\right)$, the effect size $\left(\mathrm{f}^{2}\right)$, and relevance and significance of the model paths. The corresponding results are presented in Figure 1. 
Table 3. Convergent validity and reliability.

\begin{tabular}{|c|c|c|c|c|c|c|}
\hline Constructs & Items & Loadings & Cronbach's Alpha & rho_A & CR & AVE \\
\hline \multirow{6}{*}{$\begin{array}{l}\text { Infrastructure and } \\
\text { technical equipment } \\
\text { (Teq) }\end{array}$} & TEq1 & 0.720 & \multirow[t]{6}{*}{0.882} & \multirow[t]{6}{*}{0.884} & \multirow[t]{6}{*}{0.911} & \multirow[t]{6}{*}{0.631} \\
\hline & TEq2 & 0.755 & & & & \\
\hline & TEq3 & 0.848 & & & & \\
\hline & TEq4 & 0.781 & & & & \\
\hline & TEq5 & 0.849 & & & & \\
\hline & TEq6 & 0.807 & & & & \\
\hline \multirow{2}{*}{$\begin{array}{c}\text { Educational process } \\
\text { (EdProc) }\end{array}$} & Cont & 0.904 & \multirow[t]{3}{*}{0.964} & \multirow[t]{3}{*}{0.965} & \multirow[t]{3}{*}{0.967} & \multirow[t]{3}{*}{0.595} \\
\hline & Tst & 0.946 & & & & \\
\hline Second-order construct & TAc & 0.931 & & & & \\
\hline \multirow{5}{*}{$\begin{array}{l}\text { Content of the } \\
\text { educational process } \\
\text { (Cont) }\end{array}$} & Cont1 & 0.861 & \multirow[t]{5}{*}{0.887} & \multirow[t]{5}{*}{0.889} & \multirow[t]{5}{*}{0.917} & \multirow[t]{5}{*}{0.690} \\
\hline & Cont2 & 0.885 & & & & \\
\hline & Cont3 & 0.835 & & & & \\
\hline & Cont4 & 0.803 & & & & \\
\hline & Cont5 & 0.765 & & & & \\
\hline \multirow{8}{*}{$\begin{array}{l}\text { Teaching staff } \\
\text { (Tst) }\end{array}$} & TSt1 & 0.835 & \multirow[t]{8}{*}{0.939} & \multirow[t]{8}{*}{0.940} & \multirow[t]{8}{*}{0.950} & 0.702 \\
\hline & TSt2 & 0.864 & & & & \\
\hline & TSt3 & 0.808 & & & & \\
\hline & TSt4 & 0.865 & & & & \\
\hline & TSt5 & 0.835 & & & & \\
\hline & TSt6 & 0.847 & & & & \\
\hline & TSt7 & 0.839 & & & & \\
\hline & TSt8 & 0.811 & & & & \\
\hline & TAc1 & 0.728 & 0.916 & 0.922 & 0.933 & 0.668 \\
\hline & TAc2 & 0.833 & & & & \\
\hline & TAc3 & 0.756 & & & & \\
\hline Teaching activities & TAc4 & 0.886 & & & & \\
\hline & TAc5 & 0.883 & & & & \\
\hline & TAc6 & 0.824 & & & & \\
\hline & TAc7 & 0.796 & & & & \\
\hline & Res1 & 0.765 & 0.939 & 0.942 & 0.949 & 0.674 \\
\hline & Res2 & 0.820 & & & & \\
\hline & Res3 & 0.850 & & & & \\
\hline & Res4 & 0.859 & & & & \\
\hline Research activities & Res5 & 0.798 & & & & \\
\hline & Res6 & 0.793 & & & & \\
\hline & Res7 & 0.882 & & & & \\
\hline & Res8 & 0.758 & & & & \\
\hline & $\operatorname{Res} 9$ & 0.852 & & & & \\
\hline & Prct1 & 0.817 & 0.942 & 0.943 & 0.953 & 0.742 \\
\hline & Prct2 & 0.883 & & & & \\
\hline & Prct3 & 0.867 & & & & \\
\hline Practical activities & Prct4 & 0.832 & & & & \\
\hline & Prct5 & 0.876 & & & & \\
\hline & Prct6 & 0.893 & & & & \\
\hline & Prct7 & 0.861 & & & & \\
\hline & Comp1 & 0.826 & 0.929 & 0.933 & 0.944 & 0.739 \\
\hline & Comp2 & 0.883 & & & & \\
\hline Knowledge, skills and & Comp3 & 0.867 & & & & \\
\hline competencies & Comp4 & 0.889 & & & & \\
\hline & Comp5 & 0.870 & & & & \\
\hline & Comp6 & 0.821 & & & & \\
\hline Employability & Emp1 & 0.912 & 0.713 & 0.747 & 0.873 & 0.774 \\
\hline$(\mathrm{Emp})$ & Emp2 & 0.846 & & & & \\
\hline
\end{tabular}




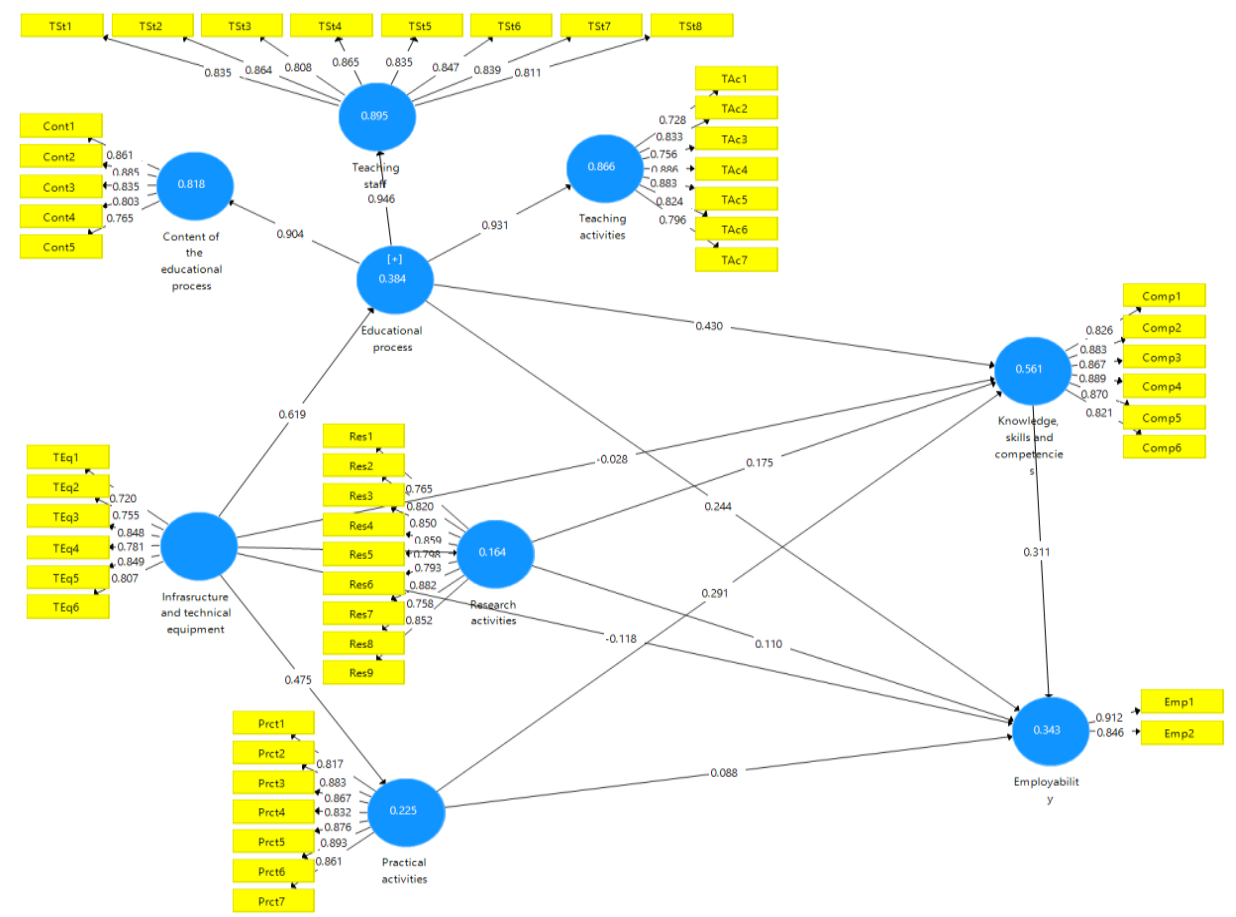

Figure 1. The Partial Least Square-Structural Equation Modelling (PLS-SEM) model. Source: Authors with SmartPls 3.2.7 (GmbH, Bönningstedt) [56].

In terms of the predictive value of the structural model, the $R$ squared $\left(R^{2}\right)$ coefficients of endogenous constructs were calculated. As can be seen in Figure 1, all of the considered quality of higher education criteria were able to explain more than half of the variance in the students' knowledge, skills, and competencies $\left(R_{\text {Comp }}^{2}=0.561\right)$, while, together with knowledge, skills, and competencies, more than one-third of the employability can be explained $\left(R_{E m p}^{2}=0.343\right)$. In terms of the effect size $\left(\mathrm{f}^{2}\right)$, the change in the $R^{2}$ of the interest variable relating to the endogenous constructs, in the case that it is excluded from the model $[55,62]$, was found to represent only a medium effect of the educational process on knowledge, skills, and competencies, a small effect on employability, and also small effects of research activities and practical activities on knowledge, skills, and competencies.

\subsection{Testing Research Hypotheses}

Within the structural model, the relevance and significance of all of the interest direct and indirect effects were assessed, examining the path coefficients, associated $t$-statistics and their bias-corrected confidence intervals, computed through a bootstrapping procedure, with 5000 resamples.

As presented in Table 4, the infrastructure and technical equipment had no direct effect on knowledge, skills, and competencies $(\beta=-0.028, n s)$ and a negative one on employability $(\beta=-0.117, p<0.05)$, thus not supporting Hypotheses 1 and 2 . A different pattern was found for the relationships between the educational process and the considered academic outcomes (knowledge, skills, and competencies and employability), since the direct effects were positive and statistically significant $(\beta=0.430, p<0.001 ; \beta=0.244, p<0.001)$, thus giving support to Hypotheses 3 and 4 . Considering the impact of practical activities on the considered academic outcomes, a positive direct effect was determined on knowledge, skills, and competencies and employability $(\beta=0.291, p<0.001)$, giving support to Hypothesis 5 , and a non-significant one on employability $(\beta=0.088, n s)$. Thus, Hypothesis 6 also cannot be supported. Finally, the data support Hypotheses 7 and 8 , since there are positive direct effects of research activities on knowledge, skills, and competencies $(\beta=0.175, p<0.001)$ and employability $(\beta=0.112, p<0.05)$. 
Table 4. Hypotheses testing (direct effects).

\begin{tabular}{cccccccc}
\hline Hypothesis & Relationship & Std. Beta & Std. Error & $\boldsymbol{t}$-Value & $\mathbf{9 5 \% ~ B C I ~}$ & Decision & $\mathbf{f}^{\mathbf{2}}$ \\
\hline H1 $(+)$ & Teq $\rightarrow$ Comp & -0.028 & 0.042 & 0.663 & $-0.101,0.038$ & Not supported & 0.001 \\
H2 $(+)$ & Teq $\rightarrow$ Emp & -0.117 & 0.050 & $2.386^{*}$ & $-0.201,-0.037$ & Not supported & 0.013 \\
H3 $(+)$ & EdProc $\rightarrow$ Comp & 0.430 & 0.050 & $8.645^{* * *}$ & $0.352,0.517$ & Supported & 0.186 \\
H4 $(+)$ & EdProc $\rightarrow$ Emp & 0.244 & 0.063 & $3.857^{* * *}$ & $0.145,0.353$ & Supported & 0.034 \\
H5 $(+)$ & Prct $\rightarrow$ Comp & 0.291 & 0.048 & $6.017^{* * *}$ & $0.207,0.365$ & Supported & 0.112 \\
H6 $(+)$ & Prct $\rightarrow$ Emp & 0.088 & 0.058 & 1.525 & $-0.009,0.183$ & Not supported & 0.006 \\
H7 $(+)$ & Res $\rightarrow$ Comp & 0.175 & 0.041 & $4.215^{* * *}$ & $0.109,0.245$ & Supported & 0.046 \\
H8 $(+)$ & Res $\rightarrow$ Emp & 0.112 & 0.053 & $2.093^{*}$ & $0.022,0.196$ & Supported & 0.012 \\
\hline
\end{tabular}

${ }^{*} p<0.05$; *** $p<0.001$; Teq-Infrastructure and technical equipment; Comp-Knowledge, skills, and competencies; Emp-Employability; EdProc-Educational process; Prct-Practical activities; Res-Research activities. Source: Authors with SmartPls 3.2.7 (GmbH, Bönningstedt) [56].

\section{Discussion}

The study developed a research model that outlined the relationships between a number of features of quality management in higher education (the quality of the educational process, the infrastructure and technical equipment, the practical activities and the students' research activities) and students' skills and employability. The results show that five out of the eight research hypotheses were supported by the collected data. Three of the supported hypotheses referred to students' knowledge, skills, and competencies, and two hypotheses were supported by the collected data referring to the chances of employment in the labor market.

Therefore, the first two supported hypotheses referred to the link between the quality of the educational process, the knowledge/competencies/skills acquired by students, and the chances of employment in the labor market. On the one hand, the findings illustrated that the quality of the educational process-represented by the quality of the content of the educational process, the quality of the teaching staff, and the quality of the teaching activities-positively and directly influenced the students' knowledge, skills, and competencies (H3). In this respect, it can be noticed that the quality of the educational process had an important role and can support the idea that the acquisition and assessment of competencies for a sustainable development of society require different ways of teaching and learning [36]. Besides, to prepare students for dealing with the complexity of sustainability issues, it is important to develop critical and interpretational competencies in students [39], and in this context, the results of this study highlight the importance of establishing a suitable curriculum and, implicitly, the importance of the quality of the educational process on developing students' competencies. On the other hand, the results show that the chances of employment in the labor market are positively and directly influenced by the quality of the educational process $(\mathrm{H} 4)$, which means that it is necessary for universities to continuously redefine the content of their disciplines in order to adapt their educational offerings to the needs of the labor market, as Sá and Serpa [8] suggest.

The third hypothesis that is supported by the data demonstrates that practical activities positively influence students' knowledge/competencies/skills. This result strengthens the idea supported by Tranca [47] that students' competencies can be improved by correlating the theoretical knowledge they acquire in the university and the competencies gained through practical activities.

The last two validated hypotheses highlight the existing relationship between the students' research activities, the knowledge/competencies/skills acquired by students, and the chances of employment in the labor market. In this connection, the findings illustrate that students' research activities have a positive direct effect on knowledge, skills, and competencies (H7), as well as on employability (H8).

For a more comprehensive image of the complex relationships between the quality of higher education constructs and academic outcomes, in addition to the direct effects described above, it is also relevant to examine the mediated effects. All of the indirect (total and specific) effects, as well as the associated $t$-statistics and their bias-corrected confidence intervals, were also determined by means of a bootstrapping procedure, with 5000 resamples [55]. 
Thus, focusing on the impact of the educational process and research activities on employability, one may see that knowledge, skills, and competencies partially mediate the relationships, since there are, simultaneously, positive direct effects $(\beta=0.244, p<0.001, \beta=0.112, p<0.05)$ and positive indirect effects $(\beta=0.133, p<0.001, \beta=0.054, p<0.001)$.

Infrastructure and technical equipment had no direct effect on knowledge, skills, and competencies $(\beta=-0.028, \mathrm{~ns})$, thus not supporting Hypothesis 1 . Therefore, considering infrastructure and technical equipment (knowledge, skills, and competencies relationship), the non-significant direct effect $(\beta=-0.028$, ns) and the positive total and specific indirect effects (Table 5, lines 1-4) mean that the educational process, practical activities, and research activities fully mediate the relationship. Therefore, it can be concluded that, at the level of higher education institutions, it is not sufficient to have a modern technical infrastructure, because, regardless of its quality, the mere existence of the infrastructure does not directly influence the development of the students' competencies; rather, it contributes to the increase in the students' abilities only if it is correlated with and appropriately used in the educational process (e.g., teachers use specific software in the teaching process) and in practical and research activities (e.g., students' access to specialized databases).

Table 5. Indirect effects.

\begin{tabular}{|c|c|c|c|c|c|}
\hline Relationship & Std. Beta & Std. Error & $t$-Value & $95 \% \mathrm{BCI}$ & Type of Mediation \\
\hline Teq $\rightarrow$ Comp $^{a}$ & 0.476 & 0.035 & $13.519^{* * *}$ & $0.419,0.535$ & \\
\hline Teq $\rightarrow$ EdProc $\rightarrow$ Comp $b$ & 0.266 & 0.034 & $7.763^{* * *}$ & $0.213,0.326$ & Full mediation \\
\hline Teq $\rightarrow$ Prct $\rightarrow$ Comp $^{b^{1}}$ & 0.138 & 0.025 & $5.517^{* * *}$ & $0.098,0.180$ & Full mediation \\
\hline Teq $\rightarrow$ Res $\rightarrow$ Comp $^{b}$ & 0.071 & 0.019 & $3.769^{* * *}$ & $0.042,0.104$ & Full mediation \\
\hline $\mathrm{Teq} \rightarrow \mathrm{Emp}^{\mathrm{a}}$ & 0.378 & 0.038 & $9.856^{* * *}$ & $0.316,0.442$ & \\
\hline Teq $\rightarrow$ Comp $\rightarrow$ Emp $^{b}$ & -0.009 & 0.014 & 0.644 & $-0.033,0.012$ & Direct-only non-mediation \\
\hline Teq $\rightarrow$ EdProc $\rightarrow$ Emp $^{b}$ & 0.151 & 0.041 & $3.649^{* * *}$ & $0.087,0.224$ & Competitive partial mediation \\
\hline Teq $\rightarrow$ Prct $\rightarrow$ Emp $^{\mathrm{b}}$ & 0.042 & 0.028 & 1.519 & $-0.003,0.088$ & Direct-only non-mediation \\
\hline Teq $\rightarrow$ Res $\rightarrow$ Emp $^{b}$ & 0.045 & 0.022 & $2.027 *$ & $0.011,0.084$ & Competitive partial mediation \\
\hline $\mathrm{Teq} \rightarrow$ EdProc $\rightarrow$ Comp $\rightarrow$ Emp $^{b}$ & 0.083 & 0.019 & $4.311^{* * *}$ & $0.055,0.120$ & Competitive partial mediation \\
\hline Teq $\rightarrow$ Prct $\rightarrow$ Comp $\rightarrow$ Emp $^{b^{1}}$ & 0.043 & 0.012 & $3.593^{* * *}$ & $0.026,0.066$ & Competitive partial mediation \\
\hline Teq $\rightarrow$ Res $\rightarrow$ Comp $\rightarrow$ Emp $^{b}$ & 0.022 & 0.007 & $3.068^{* *}$ & $0.012,0.037$ & Competitive partial mediation \\
\hline EdProc $\rightarrow$ Emp $^{a}$ & 0.133 & 0.029 & $4.567^{* * *}$ & $0.090,0.188$ & Complementary partial mediation \\
\hline Prct $\rightarrow$ Emp $^{a}$ & 0.091 & 0.024 & $3.815^{* * *}$ & $0.056,0.134$ & Full mediation \\
\hline $\operatorname{Res} \rightarrow \mathrm{Emp}^{\mathrm{a}}$ & 0.054 & 0.016 & $3.323 * * *$ & $0.031,0.085$ & Complementary partial mediation \\
\hline
\end{tabular}

Moreover, as presented in Table 4, infrastructure and technical equipment had a negative effect on employability $(\beta=-0.117, p<0.05)$, thus not supporting Hypothesis 2 . However, the mediation effect on the relationship between infrastructure and technical equipment and employability seemed to be even more complex. Therefore, considering the negative direct effect $(\beta=-0.117, p<0.05)$, and the non-significant specific indirect effect through knowledge, skills, and competencies and practical activities (Table 5, lines 6 and 8), one may conclude that those two latent variables do not act as mediators at all. However, the positive specific indirect effects (see Table 5, lines 7, 9 and 10-12), mediated by all of the other mediators, support their competitive partial mediation effect on the relationship between the infrastructure and technical equipment and employability. This means that those latent constructs and chains of constructs act as a suppressor variable, since the direct effect of infrastructure and technical equipment on employability was negative, while the specific indirect effects were positive. Thus, it can be said that infrastructure and the technical equipment did not have a positive influence on students' employment chances in the labor market, but if the educational process is carried out in modern classrooms, with equipment that allows learning through specific programs, teachers' use of information resources in the teaching process, and the integration of a number of specific practical activities, and if students have access to modular libraries and databases that enable 
them to do research, all this leads to students acquiring specific skills, which implicitly influences their chances of employability in the labor market.

Additionally, focusing on the impact of practical activities on the considered academic outcomes, a non-significant effect was determined on employability $(\beta=0.088, \mathrm{~ns})$. Thus, Hypotheses 6 also cannot be supported. Moreover, the non-significant direct effect $(\beta=0.088, \mathrm{~ns})$ and positive indirect effect $(\beta=0.091, p<0.001)$ of practical activities on employability support the full mediation of knowledge, skills, and competencies.

The findings of this study could have theoretical implications and practical implications as well. From a theoretical point of view, this study proposes a conceptual model that links the elements of quality management in higher education with students' competencies and chances of employment in the labor market, highlighting their direct and indirect relationships. Moreover, although there are other studies that analyze students' perceptions of various aspects of the subject [35-39], this study integrates them into a more comprehensive model and provides empirical evidence of their complex relationships.

From a practical perspective, the results can be of interest to higher education policy makers, specifically the institutions responsible for the evaluation and accreditation of universities, and also to students. First, this paper contributes to providing empirical evidence to higher education policy makers to support their decisions concerning the design of curricula, study programs, etc., so as to maximize their positive impact on students' competencies and employability. Moreover, by improving the curriculum, the study helps decision-makers contribute to facilitating a sustainable future, reinforcing Rieckmann's [19] idea that, to facilitate a sustainable future, universities need to include sustainability issues in their curricula in order to contribute to the creation of sustainability awareness and to develop key sustainability competencies. Second, the information provided on the specific influence of each considered quality management factor may encourage the institutions responsible for the evaluation and accreditation of universities to set their own assessment criteria, taking into account the most important quality management factors and the extent to which each of these factors contributes to increasing the skills and chances of employment in the labor market of students. Third, this paper may have positive practical implications for students. From the PLS-SEM model (Figure 1), it may be noticed that there is a link between knowledge/skills/competencies and employability, namely, competencies positively influence the chances of employment in the labor market of students. Thus, this paper presents to students the extent to which a number of elements of the quality management of the educational system may influence their skills development, which subsequently increases their chances of employability. Knowing all these factors and the implications of each factor on students' competencies and chances of employment in the labor market, students will be able to aid in facilitating a sustainable future.

\section{Conclusions}

Quality management requires a specific approach in relation to the services sector. Higher education requires increased attention relating to the assessment of issues related to the quality of educational services and their measurement [63]. This paper identified the extent to which the quality of the educational process, infrastructure and technical equipment, practices, and research activities influenced the competencies of students from two universities and the chances of their employment in the labor market. Our main contribution is the illustration of the most important elements of quality management that universities need to improve in order to develop their students' competencies and, thus, increase their chances of insertion into the labor market, given the present context of the competitiveness of universities.

From the analysis of the specialized literature, it can be concluded that, in the current context of globalization and sustainability in higher education, it is necessary for universities to provide a complex education $[18,45]$ that does not only focus on the transmission of technical abilities, but also on adapting educational offers to the needs of the labor market [8] and training students with a range of specific skills $[14,16,24]$ to help them in different professional fields. 
The results of this study may have theoretical implications and practical implications, as presented above. However, certain limitations should be considered. A first limitation of this research would be that it was not possible to identify further similar studies on this topic in the literature, which limits our ability to compare the results obtained by us with others in the field. The other limitation of the research could be that the data are collected through a single questionnaire, applied at a certain time, and the sample was restricted to two universities in Romania.

In the future, it would be useful to carry out new research at several universities and to identify other elements relating to quality management that could have positive influences on the development of competencies in students and on increasing their chances of inserting themselves into the labor market. Considering the findings of this paper, another interesting and complex issue that can be studied in future research refers to the mismatch between the competencies acquired by students and the competencies required in the world of work. Additionally, starting from the results and discussions of this study, future research may address, in more detail, the traits and implications regarding the correlation between students' competencies and employability.

Author Contributions: All authors were involved in the literature review, methodology design, data analysis, and manuscript preparation. All authors have read and approved the final manuscript.

Funding: This research received no external funding.

Acknowledgments: This study was conducted through the doctoral and post-doctoral advanced research programs, Management field, The Bucharest University of Economic Studies.

Conflicts of Interest: The authors declare no conflict of interest. 


\section{Appendix A}

Table A1. The questionnaire.

\begin{tabular}{|c|c|c|}
\hline Construct & Variables & References \\
\hline $\begin{array}{l}\text { Infrastructure and } \\
\text { technical equipment } \\
\text { (Teq) }\end{array}$ & $\begin{array}{l}\text { TEq1-The correlation between the number of seats in the classrooms and the } \\
\text { number of students in a series } \\
\text { TEq2-The correlation between the number of seats in the seminar rooms and the } \\
\text { number of students in a group } \\
\text { TEq3-Equipment of classrooms/seminars (furniture, video projectors, etc.) } \\
\text { TEq4-Facilities of sanitary groups } \\
\text { TEq5-The equipment of computer science laboratories (modern computers, etc.) } \\
\text { TEq6-The existence of appropriate software for study subjects } \\
\text { TEq7-Wireless internet access in the university }\end{array}$ & {$[21,43,44]$} \\
\hline $\begin{array}{l}\text { Content of the } \\
\text { educational process } \\
\text { (Cont) }\end{array}$ & $\begin{array}{l}\text { Cont1-The correlation between the study discipline and the profile you } \\
\text { are studying } \\
\text { Cont2-The relevance of the study disciplines } \\
\text { Cont } 3 \text {-Structure of the disciplines of study in a logical sequence } \\
\text { Cont } 4 \text {-The compatibility between what you study in the course and what you } \\
\text { study in the seminar } \\
\text { Cont5-The clear presentation of the assessment requirements in the first courses }\end{array}$ & {$[14,19,21,36,43,44]$} \\
\hline $\begin{array}{l}\text { Teaching activities } \\
\text { (TAc) }\end{array}$ & $\begin{array}{l}\text { TAc1-Number of students in a series } \\
\text { TAc2-The knowledge gained during the courses } \\
\text { TAc3-Number of students in a group } \\
\text { Tac4-Knowledge gained during seminars } \\
\text { TAc5-The relevance of the information that is transmitted } \\
\text { Tac6-Actuality of the information transmitted in the course/seminars } \\
\text { TAc7-The practical applicability of the information provided }\end{array}$ & {$[19,36,43-45]$} \\
\hline $\begin{array}{l}\text { Practical activities } \\
\text { (Prct) }\end{array}$ & $\begin{array}{l}\text { Prct1-Provision of access to the place of practice by the university } \\
\text { Prct2-Duration of specialty practice } \\
\text { Prct3-The period of the specialty practice } \\
\text { Prct4-Communication with the practice coordinator teacher } \\
\text { Prct5-Practice documentation for the final assessment (practice notebook, etc.) } \\
\text { Prct6-The concordance between the practice and the field in which you are } \\
\text { a student } \\
\text { Prct7-The way in which the specialized practice contributes to } \\
\text { professional development }\end{array}$ & {$[16,33,43,44,47]$} \\
\hline $\begin{array}{l}\text { Knowledge, skills and } \\
\text { competencies } \\
\text { (Comp) }\end{array}$ & $\begin{array}{l}\text { Comp1-Knowledge and competencies in the field of specialty } \\
\text { Comp2-Communication skills/competencies } \\
\text { Comp3-Teamwork competencies } \\
\text { Comp4-Organizational skills and competencies } \\
\text { Comp5-Analytical and problem-solving skills } \\
\text { Comp6-Entrepreneurial skills }\end{array}$ & {$[7,8,19-21,34,36,39,43,44]$} \\
\hline $\begin{array}{l}\text { Employability } \\
\text { (Emp) }\end{array}$ & $\begin{array}{l}\text { Emp1-The chances of being hired after completing your studies in the field of } \\
\text { your studies } \\
\text { Emp2-The chances of being hired after completing your studies in a related field }\end{array}$ & {$[7,8,35,43,44]$} \\
\hline
\end{tabular}

Source: authors, based on the mentioned references and survey. 


\section{References}

1. Polyakova, E.I. Business simulation as a means of developing intercultural competence. Procedia Soc. Behav. Sci. 2016, 234, 289-294. [CrossRef]

2. Dias, D.; Soares, D.; Marinho-Araújo, C.; Almenida, L.S. What is "taught" in higher education: Assessing knowledge, skills, values and attitudes. Meta. Aval. 2018, 10, 318-337. [CrossRef]

3. Langa, C. The contribution of transversal competences to the training of the educational sciences specialist. Procedia Soc. Behav. Sci. 2015, 180, 7-12. [CrossRef]

4. Sarmento, M.; Dias, M.F.; Amorim, M.; Galego, D. Transversal Competences for Employability Across Four European Countries. In Proceedings of the 12th International Technology, Education and Development Conference (INTED), Valencia, Spain, 5-7 March 2018; pp. 5200-5209. [CrossRef]

5. Hesselbein, F.; Goldsmith, M.; Beckhard, R. Organizația Viitorului; Teora: Bucharest, Romania, 2000; ISBN 109736019470.

6. Butum, L.C. The role of international competences in increasing graduates' access to the labor market. In Proceedings of the International Conference on Business Excellence, Bucharest, Romania, 30-31 March 2017; Volume 11, pp. 513-522.

7. POSDRU. Ghidul solicitantului-condiții specifice-cerere de propuneri de proiecte. Tranziția de la Școală la Viața Activă, Axa Prioritară 2 -Corelarea Învățării pe tot Parcursul Vieții cu Piața Muncii. 2013. Available online: https:// www.fonduri-structurale.ro/Document_Files//resurseumane/00000030/grewq_2.1.\%20-\%20161.pdf (accessed on 26 January 2018).

8. Sá, M.J.; Serpa, S. Transversal Competences: Their Importance and Learning Processes by Higher Education Students. Educ. Sci. 2018, 8, 126. [CrossRef]

9. Zartner, D.; Carpenter, K.; Gokcek, G.; Melin, M.; Shaw, C. Knowledge, Skills, and Preparing for the Future: Best Practices to Educate International Studies Majors for Life after College. Int. Stud. Perspect. 2018, 19, 148-169. [CrossRef]

10. Murray, J. Student-led action for sustainability in higher education: A literature review. Int. J. Sustain. High. Educ. 2018, 19, 1095-1110. [CrossRef]

11. Rusinko, C. Using quality management as a bridge in educating for sustainability in a business school. Int. J. Sustain. High. Educ. 2005, 6, 340-350. [CrossRef]

12. Brinkhurst, M.; Rose, P.; Maurice, G.; Ackerman, J.D. Achieving campus sustainability: Top-down, bottom-up, or neither? Int. J. Sustain. High. Educ. 2011, 12, 338-354. [CrossRef]

13. Fuertes-Camacho, M.T.; Graell-Martín, M.; Fuentes-Loss, M.; Balaguer-Fàbregas, M.C. Integrating Sustainability into Higher Education Curricula through the Project Method, a Global Learning Strategy. Sustainability 2019, 11, 767. [CrossRef]

14. Posch, A.; Steiner, G. Integrating research and teaching on innovation for sustainable development. Int. J. Sustain. High. Educ. 2006, 7, 276-292. [CrossRef]

15. Lozano, R.; Barreiro-Gen, M.; Lozano, F.J.; Sammalisto, K. Teaching Sustainability in European Higher Education Institutions: Assessing the Connections between Competences and Pedagogical Approaches. Sustainability 2019, 11, 1602. [CrossRef]

16. Bratianu, C.; Vatamanescu, E.M. Students' perception on developing conceptual generic skills for business A knowledge-based approach. VINE J. Inf. Knowl. Manag. Syst. 2017, 47, 490-505. [CrossRef]

17. Lambrechts, W.; Mulà, I.; Ceulemans, K.; Molderez, I.; Gaeremynck, V. The integration of competences for sustainable development in higher education: An analysis of bachelor programs in management. J. Clean. Prod. 2013, 48, 65-73. [CrossRef]

18. Gilar-Corbi, R.; Pozo-Rico, T.; Castejon-Costa, J.L. Improving Emotional Intelligence in Higher Education Students: Testing Program Effectiveness in Tree Countries. Educ. XX1 2019, 22, 161-187.

19. Rieckmann, M. Future-oriented higher education: Which key competencies should be fostered through university teaching and learning? Futures 2012, 44, 127-135. [CrossRef]

20. Wiek, A.; Withycombe, L.; Redman, C.L. Key competencies in sustainability: A reference framework for academic program development. Sustain. Sci. 2011, 6, 203-218. [CrossRef]

21. Faham, E.; Rezvanfar, A.; Mohammadi, S.H.M.; Nohooji, M.R. Using system dynamics to develop education for sustainable development in higher education with the emphasis on the sustainability competencies of students. Technol. Forecast. Soc. Chang. 2017, 123, 307-326. [CrossRef] 
22. Poza-Vilches, F.; López-Alcarria, A.; Mazuecos-Ciarra, N. A Professional Competences' Diagnosis in Education for Sustainability: A Case Study from the Standpoint of the Education Guidance Service (EGS) in the Spanish Context. Sustainability 2019, 11, 1568. [CrossRef]

23. Anderberg, E.; Nordén, B.; Hansson, B. Global learning for sustainable development in higher education: Recent trends and a critique. Int. J. Sustain. High. Educ. 2009, 10, 368-378. [CrossRef]

24. Barth, M.; Rieckmann, M. Academic staff development as a catalyst for curriculum change towards education for sustainable development: An output perspective. J. Clean. Prod. 2012, 26, 28-36. [CrossRef]

25. Novo-Corti, I.; Badea, L.; Tirca, D.M.; Aceleanu, M.I. A pilot study on education for sustainable development in the Romanian economic higher education. Int. J. Sustain. High. Educ. 2018, 19, 817-838. [CrossRef]

26. Elliott, H.; Wright, T. Barriers to sustainable universities and ways forward: A Canadian students' perspective. In Proceedings of the 3rd World Sustainability Forum, Online Conference, 1-30 November 2013.

27. Hersey, P.; Blanchard, H.K.; Johnson, E.D. Management of Organizational Behaviour: Leading Human Resources, 8th ed.; Prentice Hall: Upper Saddle River, NJ, USA, 2000; ISBN 13 978-0130325181.

28. Hey, R.B. Performance Management for the Oil, Gas, and Process Industries: A Systems Approach; Chapter 20; Elsevier: Cambridge, MA, USA, 2017.

29. Herppich, S.; Praetorius, A.K.; Förster, N.; Glogger-Frey, I.; Karst, K.; Leutner, D.; Behrmann, L.; Böhmer, M.; Ufer, S.; Klug, J. Teachers' assessment competence: Integrating knowledge-, process-, and product-oriented approaches into a competence-oriented conceptual model. Teach. Teach. Educ. 2018, 76, 181-193. [CrossRef]

30. Dada, J.O.; Jagboro, G.O. A framework for assessing quantity surveyors' competence. Benchmarking Int. J. 2018, 25, 2390-2403. [CrossRef]

31. Knight, P.T.; Yorke, M. Assessment, Learning and Employability; McGraw-Hill Education: Maidenhead, UK, 2003.

32. Knight, P.T.; Yorke, M. Employability and Good Learning in Higher Education. Teach. High. Educ. 2003, 8. [CrossRef]

33. Bjornali, E.; Støren, L.A. Examining competence factors that encourage innovative behaviour by European higher education graduate professionals. J. Small Bus. Enterp. Dev. 2012, 19, 402-423. [CrossRef]

34. Ploum, L.; Blok, V.; Lans, T.; Omta, O. Toward a Validated Competence Framework for Sustainable Entrepreneurship. Organ. Environ. 2018, 31, 113-132. [CrossRef] [PubMed]

35. Nicolescu, L.; Nicolescu, C. Using PLS-SEM to build an employability confidence model for higher education recipients in the field of business studies. Kybernetes 2019. [CrossRef]

36. Lambrechts, W.; Van Petegem, P. The interrelations between competences for sustainable development and research competences. Int. J. Sustain. High. Educ. 2016, 17, 776-795. [CrossRef]

37. Kagawa, F. Dissonance in students' perceptions of sustainable development and sustainability: Implications for curriculum change. Int. J. Sustain. High. Educ. 2007, 8, 317-338. [CrossRef]

38. Zsóka, Á.; Szerényi, Z.M.; Széchy, A.; Kocsis, T. Greening due to environmental education? Environmental knowledge, attitudes, consumer behavior and everyday pro-environmental activities of Hungarian high school and university students. J. Clean. Prod. 2013, 48, 126-138. [CrossRef]

39. Lambrechts, W.; Ghijsen, P.W.T.; Jacques, A.; Walravens, H.; Van Liedekerke, L.; Van Petegem, P. Sustainability segmentation of business students: Toward self-regulated development of critical and interpretational competences in a post-truth era. J. Clean. Prod. 2018, 202, 561-570. [CrossRef]

40. Waltner, E.-M.; Rieß, W.; Mischo, C. Development and Validation of an Instrument for Measuring Student Sustainability Competencies. Sustainability 2019, 11, 1717. [CrossRef]

41. Čepić, R.; Vorkapic, S.T.; Loncaric, D.; Andic, D.; Mihic, S.S. Considering Transversal Competences, Personality and Reputation in the Context of the Teachers' Professional Development. Int. Educ. Stud. 2015, 8, 8-20. [CrossRef]

42. ENQA. Standards and Guidelines for Quality Assurance in the European Higher Education Area (ESG); ENQA: Brussels, Belgium, 2015; Available online: https:/enqa.eu/wp-content/uploads/2015/11/ESG_2015.pdf (accessed on 3 December 2018).

43. ARACIS. Metodologia de Evaluare Externă, Standardele de Referință și Lista Indicatorilor de Performanță a Agenției Române de Asigurare a Calității în Invătământul Superior; ARACIS: Bucharest, Romania, 2006; Available online: http://www.aracis.ro/fileadmin/ARACIS/Proceduri/Metodologie_de_evaluare_externa.pdf (accessed on 26 January 2018). 
44. ARACIS. Fișa Vizitei Acreditare/Evaluare Periodică; ARACIS: Bucharest, Romania, 2018; Available online: http://www.aracis.ro/fileadmin/ARACIS/Comunicate_Media/2013/Fise_IF/Fisa_vizitei-_Acreditare_ _Evaluare_periodica.pdf (accessed on 26 January 2018).

45. Huiszoon, G. Innovating Higher Education and Faculty Competences by Performing Practice Based Research. In Proceedings of the 12th International Technology, Education and Development Conference (INTED), Valencia, Spain, 5-7 March 2018; pp. 268-271.

46. Karna, H.; Gotovac, S. Evaluating Expert Estimators Based on Elicited Competences. J. Inf. Organ. Sci. 2015, 39, 49-63.

47. Tranca, L.M. Competences of Students in Social Work from the Perspective of Practical Work Supervisors in the Field of Delinquency. In Proceedings of the International Conference of Multidisciplinary Perspectives in the Quasi-Coercive Treatment of Offenders, Timișoara, Romania, 31 March-1 April 2016; pp. 248-253.

48. Balcar, J.; Janickova, L.; Filipova, L. What general competencies are required from the Czech labour force? Prague Econ. Pap. 2014, 23, 250-265. [CrossRef]

49. Pinto, S. Intercultural competence in higher education: academics' perspectives. Horiz. 2018, 26, 137-147. [CrossRef]

50. Webster, C.M.; Kenney, J. Embedding research activities to enhance student learning. Int. J. Educ. Manag. 2011, 25, 361-377. [CrossRef]

51. Simons, M.; Elen, J. The 'research-teaching nexus' and 'education through research': An exploration of ambivalences. Stud. High. Educ. 2007, 32, 617-631. [CrossRef]

52. Brew, A. Imperatives and challenges in integrating teaching and research. High. Educ. Res. Dev. 2010, 29, 139-150. [CrossRef]

53. Evans, J.R.; Mathur, A. The value of online surveys. Internet Res. 2005, 15, 195-219. [CrossRef]

54. Hair, J.F.; Ringle, C.M.; Sarstedt, M. PLS-SEM: Indeed a Silver Bullet. J. Mark. Theory Pract. 2011, 19, $139-152$. [CrossRef]

55. Hair, J.F., Jr.; Hult, G.T.; Ringle, C.M.; Sarstedt, M. A Primer on Partial Least Squares Structural Equation Modeling (PLS-SEM), 2nd ed.; SAGE: Thousand Oaks, CA, USA, 2017.

56. Ringle, C.M.; Wende, S.; Becker, J.M. SmartPLS 3.2.7; SmartPLS GmbH: Bönningstedt, Germany, 2015.

57. IBM Corp. IBM SPSS Statistics for Windows, Version 25.0 [Computer Program]; IBM Corp.: Armonk, NY, USA, 2017.

58. Hair, J.F.; Black, W.C.; Bobin, B.J.; Anderson, N.E. Multivariate Data Analysis, 7th ed.; Pearson Prentice Hall: Upper Saddle River, NJ, USA, 2010.

59. Hulland, J. Use of partial least squares (PLS) in strategic management research: A review of four recent studies. Strateg. Manag. J. 1999, 20, 195-204. [CrossRef]

60. Fornell, C.; Larcker, D. Evaluating Structural Equation Models with Unobservable Variables and Measurement Error. J. Mark. Res. 1981, 18, 39-50. [CrossRef]

61. Nunnaly, J.C.; Bernstein, I.R. Psychometric Theory, 3rd ed.; McGraw-Hill: New York, NY, USA, 1994.

62. Cohen, J. Statistical Power Analysis for the Behavioral Sciences, 2nd ed.; Lawrence Erlbaum Associates: New York, NY, USA, 1988.

63. Annamdevula, S.; Bellamkonda, R.S. The effects of service quality on student loyalty: The mediating role of student satisfaction. J. Model. Manag. 2019, 11, 446-462. [CrossRef]

(C) 2019 by the authors. Licensee MDPI, Basel, Switzerland. This article is an open access article distributed under the terms and conditions of the Creative Commons Attribution (CC BY) license (http://creativecommons.org/licenses/by/4.0/). 